\title{
Effect of heat treatment on cytotoxicity of self-adhesive resin cements: Cell viability analysis
}

\author{
Celso Afonso Klein-Júnior ${ }^{1}$, Roberto Zimmer ${ }^{1}$, Guilherme Scotta Hentschke ${ }^{2}$, \\ Denise Cantarelli Machado ${ }^{3}$, Rubem Beraldo dos Santos ${ }^{1}$, Eduardo Galia Reston ${ }^{1}$
}

Correspondence: Dr. Celso Afonso Klein-Júnior

Email: profcelsoklein@gmail.com

\begin{abstract}
'Department of Operative Dentistry, School of Dentistry, Lutheran University of Brazil, Cachoeira do Sul, Rio Grande do Sul, Brazil, 2Department of Cell Biology, Lutheran University of Brazil, Cachoeira do Sul, Rio Grande do Sul, Brazil, ${ }^{3}$ Neuroscience Department, Brain Institute, Neuroscience Laboratory, Pontifical Catholic University of Rio Grande do Sul, Rio Grande do Sul, Brazil
\end{abstract}

\section{ABSTRACT}

Objective: The aim of the study was to assess, in vitro, the influence on cytotoxicity of heat treatment applied before photopolymerization, while mixing three self-adhesive resin cements, in an NIH/3T3 fibroblast cell culture, based on cell viability measures. Methods: Samples were divided into three groups: (1) no heat treatment while mixing (control), (2) $37^{\circ} \mathrm{C}$, and (3) $60^{\circ} \mathrm{C}$ heat treatment while mixing. Cements were light-cured immediately after mixing and immersed in Dulbecco's Modified Eagle Media for the extraction of possibly uncured products after $24 \mathrm{~h}$ and 7 days. Cultures contained $0.5 \mathrm{~mL}$ of NIH/3T3 fibroblasts per well at a concentration of $0.4 \times 10^{5} \mathrm{cell} / \mathrm{sLL}$ and specific extracts for each sample. Statistical Analysis Used: Data were statistically analyzed with ANOVA and post hoc Student-Newman-Keuls (significance of 5\%). Results: Cement cytotoxicity increased with time, as shown by the higher values observed at 7 days. There was a slight difference in intragroup cytotoxicity levels between $24 \mathrm{~h}$ and 7 days. Heat treatment at $60^{\circ} \mathrm{C}$ was associated with a major decrease in cytotoxicity levels in all three groups, both at $24 \mathrm{~h}$ and at 7 days, with no differences among the cements. Conclusions: Heat treatment at $60^{\circ} \mathrm{C}$ should be considered as a strategy to reduce cytotoxicity of self-adhesive resin cements, as evidenced by the results observed at $24 \mathrm{~h}$ and 7 days of analysis.

Key words: Biocompatibility, dental materials, toxic substances

\section{INTRODUCTION}

With the evolution of esthetic dentistry, self-adhesive resin cements have become indispensable in clinical practice. These materials are used in several procedures, for example, cementation of indirect restorations, porcelain laminate veneers, and fixed prostheses, especially because of their low solubility in water and the strength of their bond to enamel and dentin. ${ }^{[1,2]}$ Because of these properties, the use of

\begin{tabular}{|l|l|}
\hline \multicolumn{2}{|c|}{ Access this article online } \\
\hline Quick Response Code: \\
\hline
\end{tabular}

self-adhesive resin cements is associated with a lower degree of infiltration and marginal staining, lower postoperative sensitivity, in addition to reinforcement of the bond between the restoration and the tooth. ${ }^{[3,4]}$ The large number of resin cements available in the market and the introduction of self-adhesive systems have increased their use in clinical practice, especially

This is an open access journal, and articles are distributed under the terms of the Creative Commons Attribution-NonCommercial-ShareAlike 4.0 License, which allows others to remix, tweak, and build upon the work non-commercially, as long as appropriate credit is given and the new creations are licensed under the identical terms.

For reprints contact: reprints@medknow.com

How to cite this article: Klein-Júnior CA, Zimmer R, Hentschke GS, Machado DC, dos Santos RB, Reston EG. Effect of heat treatment on cytotoxicity of self-adhesive resin cements: Cell viability analysis. Eur $\mathrm{J}$ Dent 2018;12:281-6.

DOI: 10.4103/ejd.ejd_34_18 
because they simplify the cementation technique, eliminating the need for previous treatment of the tooth substrate and decreasing sensitivity. In addition, these cements present a strong bond to dentin, similar to that of conventional adhesive cements. ${ }^{[-7]}$

Adequate conversion of monomers into polymers is essential to maximize the physical properties and clinical performance of resin cements, as well as to reduce their cytotoxicity. ${ }^{[8]}$ Polymerization may be influenced by several factors, for example, ceramic translucency, ${ }^{[9,10]}$ thickness, ${ }^{[9,11,12]}$ curing time, ${ }^{[13]}$ type of curing unit, ${ }^{[14,15]}$ battery level, ${ }^{[16]}$ light intensity, wavelength, and type of initiator. ${ }^{[17]}$ Different types of curing light units have been proposed and assessed for the photopolymerization of restorative materials, always with the goal of enhancing physical properties and clinical performance and consequently reducing cytotoxicity. ${ }^{[18-20]}$

Several attempts have been made over recent years to enhance polymerization rates, and it is currently known that the molecular cross-linking density of methacrylate-based resin materials can be improved with the use of high temperatures either before or during polymerization. ${ }^{[21,22]}$ Several authors have demonstrated superior physical properties of resin materials as a result of a higher degree of conversion of monomers into polymers obtained through different light-curing methods employing heat. ${ }^{[23-26]}$

Cytotoxicity measurement based on cellular behavior and viability is the first step in assessing the biocompatibility of dental materials for subsequent use in clinical practice. ${ }^{[27]}$ Cytotoxicity depends on the quality and amount of monomers and derivatives released, which may irritate the pulp and oral soft tissues and eventually lead to a toxic reaction. ${ }^{[28,29]}$ Methacrylate-based dental materials are known to present a high level of cytotoxicity and are therefore likely to penetrate the pulp and induce cytotoxic effects. ${ }^{[30]}$

Several protocols have been used to assess cellular behavior, viability, and cytotoxicity, including the trypan blue exclusion assay, chromium release assay, DNA synthesis, and cellular metabolism (3-(4,5-dimethylthiazol-2-yl)-2,5-diphenyltetrazolium bromide [MTT]) assay. In particular, the MTT is considered a relatively simple assay, yet as thorough and reliable as the others, and therefore it is widely used to determine cytotoxicity of different materials in cell cultures. ${ }^{[31-33]}$
The objective of this study was to assess, in vitro, the influence on cytotoxicity of heat treatment applied before photopolymerization, while mixing three self-adhesive resin cements, in an NIH/3T3 fibroblast cell culture, based on cell viability measures.

\section{METHODS}

\section{Sample preparation}

Three self-adhesive resin cements were used in this in vitro study: RelyX U200 (3M ESPE, Saint Paul, Minnesota, USA), Multilink N (Ivoclar Vivadent, Schaan, Liechtenstein), and BisCem (Bisco Inc., Schaumburg, Illinois, USA) [Table 1]. Resin cement dispensers were sterilized with ethylene oxide (Esteriliplus, Porto Alegre, Rio Grande do Sul, Brazil), and the necessary amounts of base and catalyst paste to produce specimens $(9 \mathrm{~mm}$ diameter $\times 1 \mathrm{~mm}$ thickness) were dispensed onto a sterilized glass slide. Specimens were immediately prepared in three different forms: (1) no heat treatment while mixing the pastes (control); (2) jet of warm air $\left(37^{\circ} \mathrm{C}\right)$ distant $10 \mathrm{~cm}$ from the slide for $10 \mathrm{~s}$ while mixing; and (3) jet of hot air $\left(60^{\circ} \mathrm{C}\right)$ distant $10 \mathrm{~cm}$ from the slide for $10 \mathrm{~s}$ while mixing. All specimens were subsequently light cured for $20 \mathrm{~s}$ using a VALO Cordless light-emitting diode curing unit (Ultradent, Salt Lake City, Utah, USA).

\section{Cell culture}

The cells used in this study were NIH/3T3 mouse fibroblasts $\left(\mathrm{ATCC}^{\circledR}\right.$-American Type Culture Collection-TCC, Old Town, Maryland, USA) cultured in Dulbecco's Modified Eagle Media (DMEM; Invitrogen ${ }^{\circledR}$, Carlsbad, California, USA). This medium was supplemented with $10 \%$ of fetal bovine serum, $100 \mathrm{U} / \mathrm{mL}$ of penicillin (Gibco), $100 \mathrm{U} / \mathrm{mL}$ of streptomycin (Gibco), and $100 \mu \mathrm{g} / \mathrm{mL}$ of gentamycin (Gibco). Cells were kept in a humidified incubator at a temperature of $37^{\circ} \mathrm{C}$ and $5 \%$ of $\mathrm{CO}_{2}$.

\section{Extraction medium}

Immediately after the light-curing process, specimens from the three groups were immersed in the DMEM medium. The specimen surface area to medium volume ratio was $3 \mathrm{~cm}^{2} / \mathrm{mL}$, according to ISO 10993-12. Surface area was calculated based on the total dimensions of the specimen, disregarding porosity. Extracts were tested for cell viability after remaining $24 \mathrm{~h}$ and 7 days in the incubator.

\section{Cytotoxicity assay}

The MTT method was used to assess cytotoxicity. This assay measures the ability of live cells to 
reduce 3-(4,5-dimethyl-2-thiazolyl)-2,5-diphenyl2H-tetrazolium bromide (MTT, Sigma) to insoluble blue-to-purple formazan crystals. At each treatment time ( $24 \mathrm{~h}$ and 7 days), the culture medium was removed and $10 \%$ of an MTT solution $(5 \mathrm{mg} / \mathrm{mL})$ in phosphate-buffered solution was added to each well. Subsequently, cultures were incubated at $37^{\circ} \mathrm{C}$, protected from light, until the presence of blue-to-purple formazan crystals was observed. For the solubilization of formazan crystals, $100 \mu \mathrm{L}$ of dimethyl sulfoxide was added to each well, and absorbance was measured at $570 \mathrm{~nm}$ wavelength using a spectrophotometer and an ELISA microplate reader (Benchmark Microplate Reader, Bio-Rad Inc., Hercules, California, USA). The percentage of viable cells was calculated and compared to the results obtained with the negative control (cells cultured in DMEM). The assay was validated using a positive toxicity control (cells treated with $2 \%$ sodium hypochlorite).

\section{Statistical analysis}

The cytotoxicity of light-cured self-adhesive resin cements without previous heat treatment and with warm and hot air treatment was compared in terms of cell viability rates in NIH/3T3 mouse fibroblast cultures using three-way ANOVA followed by post hoc Student-Newman-Keuls. Examiners were blinded to group allocation. Results were expressed as mean and standard deviation. Significance was set at $5 \%$.

\section{RESULTS}

Table 2 shows the cell viability results obtained for the three self-adhesive resin cements. Groups treated with both temperatures $\left(37^{\circ} \mathrm{C}\right.$ and $\left.60^{\circ} \mathrm{C}\right)$ showed cytotoxicity, with a reduced number of viable cells, regardless of the cement used. Resin cement cytotoxicity increased with time, with the highest values observed at 7 days for all cements.

At the $24 \mathrm{~h}$ cell viability analysis, no differences were detected among the samples not subjected to heat treatment in terms of cell viability. In the samples treated with warm air $\left(37^{\circ} \mathrm{C}\right), 24 \mathrm{~h}$ cell viability results were similar to those obtained without heat treatment in both RelyX and BisCem samples. Multilink N, in turn, showed a significantly lower cell viability rate. Finally, in the samples treated with hot air $\left(60^{\circ} \mathrm{C}\right)$, all three cements showed higher cell viability rates when compared to either the warm air group $\left(37^{\circ} \mathrm{C}\right)$ or the group with no heat treatment. However, no differences were observed among the three self-adhesive resin cements subjected to $60^{\circ} \mathrm{C}$ heat treatment.

After 7 days of incubation, in turn, cell viability rates were lower than those obtained at $24 \mathrm{~h}$ in both the group treated with warm air $\left(37^{\circ} \mathrm{C}\right)$ and in the one not subjected to heating. Conversely, in the group treated with hot air $\left(60^{\circ} \mathrm{C}\right)$, cell viability results showed a marked increase when compared with the nonheated group, in all self-adhesive resin cements.

\begin{tabular}{|c|c|c|c|c|}
\hline Cement & Composition & Light-curing time (s) & Batch & Manufacturer \\
\hline RelyX U200 & $\begin{array}{l}\text { Silanated filler (glass powder), dimethacrylate monomers, } \\
\text { 1-benzyl-5-phenylbarbituric acid, calcium salt, 1,12-dodecanediol } \\
\text { dimethacrylate, sodium p-toluenesulfonate, silanated silica, } \\
\text { calcium hydroxide, methacrylated aliphatic amine, titanium dioxide }\end{array}$ & 20 & 622725 & 3M ESPE \\
\hline Multilink N & $\begin{array}{l}\text { Dimethacrylate, HEMA, barium glass, ytterbium } \\
\text { trifluoride, spherical mixed oxides }\end{array}$ & 20 & U44037 & Ivoclar \\
\hline BisCem & $\begin{array}{l}\text { Bis-GMA, dimethacrylate monomer, glass particles, and acid } \\
\text { monomer }\end{array}$ & 20 & 1500003825 & Bisco \\
\hline
\end{tabular}

\begin{tabular}{|c|c|c|c|c|c|c|}
\hline \multirow[t]{2}{*}{ Cement } & \multicolumn{3}{|c|}{$24 \mathrm{~h}$} & \multicolumn{3}{|c|}{7 days } \\
\hline & No heat & $37^{\circ} \mathrm{C}$ & $60^{\circ} \mathrm{C}$ & No heat & $37^{\circ} \mathrm{C}$ & $60^{\circ} \mathrm{C}$ \\
\hline RelyX & $14.93 \pm 1.77^{\mathrm{A}}$ & $14.56 \pm 0.71^{A, C}$ & $23.25 \pm 0.45^{\mathrm{B}}$ & $5.41 \pm 0.68^{\mathrm{D}}$ & $6.24 \pm 1.73^{\mathrm{D}}$ & $14.70 \pm 0.65^{\mathrm{A}}$ \\
\hline Multilink N & $13.93 \pm 1.35^{\mathrm{A}}$ & $12.24 \pm 1.15^{\mathrm{C}}$ & $24.05 \pm 0.40^{\mathrm{B}}$ & $6.33 \pm 1.06^{\mathrm{F}}$ & $8.43 \pm 0.61^{F}$ & $15.31 \pm 1.15^{\mathrm{A}}$ \\
\hline BisCem & $15.52 \pm 1.37^{A}$ & $15.89 \pm 0.30^{A}$ & $23.88 \pm 1.05^{\mathrm{B}}$ & $5.78 \pm 0.69^{D}$ & $6.77 \pm 0.77^{\mathrm{D}}$ & $13.87 \pm 0.68^{A, C}$ \\
\hline
\end{tabular}


Furthermore, samples treated with hot air $\left(60^{\circ} \mathrm{C}\right)$ were able to maintain high rates of cell viability, showing similar results to those found at $24 \mathrm{~h}$ in the group not subjected to heat treatment. Again, the three groups treated with hot air showed similar cell viability results among themselves.

\section{DISCUSSION}

Several studies have been conducted over the past few years to analyze the biocompatibility of methacrylate-based resin materials, which are known to have severe cytotoxic effects on pulp tissues. In the present study, we measured cell viability rates in the extraction medium in contact with cells after $24 \mathrm{~h}$ and 7 days of incubation. Not only did we confirm the presence of toxicity in resin cements but also we found that toxicity increases significantly with time.

Cell characteristics and functions have been used to analyze and investigate cytotoxicity of methacrylate-based resin materials. Cell adhesion, proliferation, and metabolism in 3T3, L929, and W138 fibroblast and osteoblast cell lines are among the parameters that have been investigated. ${ }^{[31,33,34]}$ In the present study, we assessed the behavior of mouse fibroblasts according to modified parameters of Stanford. Although these cells are more sensitive to cytotoxicity than human cells, they are indicated for this type of study by the American National Standard ISO 10993-5 due to their reproducible growth rates, easy handling, and easy availability when compared with primary cells and in addition being an immortal cell line. ${ }^{[31]}$ Cell inviability as determined by the MTT test does not necessarily mean a higher occurrence of apoptosis and tissue necrosis; rather, it means that, in addition to these events, there may also be a higher number of cells showing reduced metabolic activity.

In this study, resin dispensers were sterilized and placed onto sterilized glass slides. Then, the base and catalyst pastes were mixed ( $9 \mathrm{~mm}$ diameter $\times 1 \mathrm{~mm}$ thickness), light cured, and immediately immersed in the monomer extraction medium. It is important that materials are tested immediately after photopolymerization, to avoid the loss of toxic substances that may be released by the material after light curing. The longer the time elapsed between photopolymerization and cell viability analysis, the less faithful and consequently less reliable the results will be. Studies have demonstrated ${ }^{[28]}$ the relevance of immediate versus late cytotoxicity analysis of methacrylate-based resin materials and its effects on cell vitality, ${ }^{[28-30]}$ as well as the importance of effective photopolymerization in an attempt to minimize cytotoxicity. ${ }^{[8]}$

Dioguardi et al. ${ }^{[35]}$ tested five different resin cements for cytotoxicity and found differences between the brands assessed. Still, all cements presented low cytotoxicity rates, which remained low even after 1 week of contact with cells. We did not confirm these findings of low cytotoxicity in the present study. On the contrary, all toxicity values were high, in all cements analyzed, both at the $24 \mathrm{~h}$ and at the 7-day analyses. In addition, in our sample, cell viability continued to reduce with time, as observed on the 7-day analysis.

Residual uncured monomers released during the light-curing process are one of the factors responsible for the cytotoxicity of resin materials. However, according to Goldberg, ${ }^{[28]}$ there are other mechanisms that contribute to cy totoxicity, for example, leachable components created by erosion or degradation over time, ion release, and bacteria located at the interface between the tooth and the adhesive.

Uncured resin cement debris, such as monomers, degradation products, initiators, activators, or stabilizers, produces cellular cytotoxicity. These products can be reduced through enhancement of the polymerization process, as better cross-linking will result in a better polymer. Heat treatment applied during the mixing of base and catalyst pastes before polymerization has enabled a good reduction rate, according to some studies, ${ }^{[21,22]}$ producing a resin with superior properties. In the present study, heat treatment at $60^{\circ} \mathrm{C}$ probably resulted in a higher rate of polymer cross-linking (enhanced polymerization) and thus fewer residual monomers.

Ergun et al ${ }^{[8]}$ reports that effective polymerization is one of the most important factors when dealing with methacrylate-based dental materials so as to improve their physical properties, clinical performance, and biocompatibility. Klein-Júnior et al. ${ }^{[25]}$ and Ferracane and Condon ${ }^{[23]}$ also showed that heat treatment before resin polymerization had a significant influence on material properties. In the present study, samples not treated with a jet of hot air $\left(60^{\circ} \mathrm{C}\right)$ showed high cytotoxicity levels, at both $24 \mathrm{~h}$ and 7 days. Conversely, in the group treated with hot air $\left(60^{\circ} \mathrm{C}\right)$ before polymerization, cytotoxicity results decreased, again at both $24 \mathrm{~h}$ and 7 days.

Resin cement cytotoxicity is known to increase with time. ${ }^{[35]}$ In the present study, we compared cytotoxicity 
results after $24 \mathrm{~h}$ and 7 days of incubation. The results showed that heat treatment had a significant effect in preventing the increase of cytotoxicity. Samples treated with a jet of hot air $\left(60^{\circ} \mathrm{C}\right)$ showed 7-day cell viability rates similar to those observed in nonheated samples at $24 \mathrm{~h}$. This finding is extremely relevant, as it suggests that heat treatment helps maintain better cell viability rates when compared with nonheated samples.

There is a great concern that cytotoxicity mechanisms may be related to the release of residual monomers during the conversion of monomers into polymers, i.e., to the early stages of polymerization. ${ }^{[28]}$ In this sense, the present study obtained markedly satisfactory results during early polymerization, as heat treatment probably allowed for a higher degree of polymer cross-linking and consequently resulted in a lower number of residual monomers.

Heat treatment before photopolymerization significantly increases monomer conversion rates to above the levels observed with traditional methods. ${ }^{[36]}$ This can be explained by the lower viscosity and increased mobility of radicals as a result of heating. Moreover, the frequency of collision of active groups and nonreacted radicals increases when curing temperature is below the glass transition temperature, resulting in additional polymerization and a higher rate of conversion. ${ }^{[37-40]}$

According to the present results, small physical modifications to the environment where cement mixing and homogenization take place, for example, using a jet of hot air at $60^{\circ} \mathrm{C}$ to heat the cement and glass slide, can play major roles in reducing material cytotoxicity. Further studies are warranted to evaluate how this cytotoxicity can be further reduced and thus cause less damage to patients.

\section{CONCLUSIONS}

The results obtained in the present study showed that heat treatment at $60^{\circ} \mathrm{C}$, before photopolymerization, while mixing self-adhesive resin cements, should be considered as a strategy to reduce cytotoxicity of self-adhesive resin cements, as evidenced by the results observed both at $24 \mathrm{~h}$ and 7 days of analysis.

\section{Financial support and sponsorship}

Nil.

\section{Conflicts of interest}

There are no conflicts of interest.

\section{REFERENCES}

1. Lee IB, Um CM. Thermal analysis on the cure speed of dual cured resin cements under porcelain inlays. J Oral Rehabil 2001;28:186-97.

2. Anchieta RB, Rocha EP, de Almeida EO, Junior AC, Martini AP. Bonding all-ceramic restorations with two resins cement techniques: A clinical report of three-year follow-up. Eur J Dent 2011;5:478-85.

3. Burke FJ, Watts DC. Fracture resistance of teeth restored with dentin-bonded crowns. Quintessence Int 1994;25:335-40.

4. Hikita K, Van Meerbeek B, De Munck J, Ikeda T, Van Landuyt K, Maida $\mathrm{T}$, et al. Bonding effectiveness of adhesive luting agents to enamel and dentin. Dent Mater 2007;23:71-80.

5. De Munck J, Vargas M, Van Landuyt K, Hikita K, Lambrechts P, Van Meerbeek B, et al. Bonding of an auto-adhesive luting material to enamel and dentin. Dent Mater 2004;20:963-71.

6. Abo-Hamar SE, Hiller KA, Jung H, Federlin M, Friedl KH, Schmalz G, et al. Bond strength of a new universal self-adhesive resin luting cement to dentin and enamel. Clin Oral Investig 2005;9:161-7.

7. Hitz T, Stawarczyk B, Fischer J, Hämmerle CH, Sailer I. Are self-adhesive resin cements a valid alternative to conventional resin cements? A laboratory study of the long-term bond strength. Dent Mater 2012;28:1183-90

8. Ergun G, Egilmez F, Yilmaz S. Effect of reduced exposure times on the cytotoxicity of resin luting cements cured by high-power led. J Appl Oral Sci 2011;19:286-92.

9. Ilie N, Hickel R. Correlation between ceramics translucency and polymerization efficiency through ceramics. Dent Mater 2008;24:908-14.

10. Archegas LR, de Menezes Caldas DB, Rached RN, Soares P, Souza EM. Effect of ceramic veneer opacity and exposure time on the polymerization efficiency of resin cements. Oper Dent 2012;37:281-9.

11. Borges GA, Agarwal P, Miranzi BA, Platt JA, Valentino TA, dos Santos $\mathrm{PH}$, et al. Influence of different ceramics on resin cement knoop hardness number. Oper Dent 2008;33:622-8.

12. Kilinc E, Antonson SA, Hardigan PC, Kesercioglu A. The effect of ceramic restoration shade and thickness on the polymerization of light- and dual-cure resin cements. Oper Dent 2011;36:661-9.

13. Silikas N, Eliades G, Watts DC. Light intensity effects on resin-composite degree of conversion and shrinkage strain. Dent Mater 2000;16:292-6.

14. Flury S, Lussi A, Hickel R, Ilie N. Light curing through glass ceramics with a second- and a third-generation LED curing unit: Effect of curing mode on the degree of conversion of dual-curing resin cements. Clin Oral Investig 2013;17:2127-37.

15. Watanabe H, Kazama R, Asai T, Kanaya F, Ishizaki H, Fukushima M, et al. Efficiency of dual-cured resin cement polymerization induced by high-intensity LED curing units through ceramic material. Oper Dent 2015;40:153-62.

16. Pereira AG, Raposo L, Teixeira D, Gonzaga R, Cardoso IO, Soares CJ, et al. Influence of battery level of a cordless LED unit on the properties of a nanofilled composite resin. Oper Dent 2016;41:409-16.

17. Moszner N, Salz U, Zimmermann J. Chemical aspects of self-etching enamel-dentin adhesives: A systematic review. Dent Mater 2005;21:895-910.

18. Obici AC, Sinhoreti MA, de Goes MF, Consani S, Sobrinho LC. Effect of the photo-activation method on polymerization shrinkage of restorative composites. Oper Dent 2002;27:192-8.

19. International Organization for Standardization. ISO 1099312 Biological Evaluation of Medical Devices. Part 12: Sample Preparation and Reference Materials. Geneva: International Organization for Standardization; 2002.

20. Price RB, Felix CA, Andreou P. Evaluation of a second-generation LED curing light. J Can Dent Assoc 2003;69:666.

21. Dolez P, Marek M, Love BJ. Photopolymerizable acrylic resin: Effect of curing time and temperature. J Appl Polym Sci 2001;82:546-54.

22. Trujillo M, Newman SM, Stansbury JW. Use of near-IR to monitor the influence of external heating on dental composite photopolymerization. Dent Mater 2004;20:766-77.

23. Ferracane JL, Condon JR. Post-cure heat treatments for composites: Properties and fractography. Dent Mater 1992;8:290-5.

24. Reinhardt JW, Boyer DB, Stephens NH. Effects of secondary curing on indirect posterior composite resins. Oper Dent 1994;19:217-20.

25. Klein-Júnior CA, Zander-Grande C, Amaral R, Stanislawczuk R, Garcia EJ, Baumhardt-Neto R, et al. Evaporating solvents with a warm 
air-stream: Effects on adhesive layer properties and resin-dentin bond strengths. J Dent 2008;36:618-25.

26. Souza RO, Ozcan M, Michida SM, de Melo RM, Pavanelli CA, Bottino MA, et al. Conversion degree of indirect resin composites and effect of thermocycling on their physical properties. J Prosthodont 2010;19:218-25.

27. Stanley HR. Biological evaluation of dental materials. Int Dent J 1992;42:37-46.

28. Goldberg M. In vitro and in vivo studies on the toxicity of dental resin components: A review. Clin Oral Investig 2008;12:1-8.

29. Bakopoulou A, Mourelatos D, Tsiftsoglou AS, Giassin NP, Mioglou E, Garefis P, et al. Genotoxic and cytotoxic effects of different types of dental cement on normal cultured human lymphocytes. Mutat Res 2009;672:103-12.

30. al-Fawaz A, Gerzina TM, Hume WR. Movement of resin cement components through acid-treated dentin during crown cementation in vitro. J Endod 1993;19:219-23.

31. Retamoso LB, Luz TB, Marinowic DR, Machado DC, De Menezes LM, Freitas MP, et al. Cytotoxicity of esthetic, metallic, and nickel-free orthodontic brackets: Cellular behavior and viability. Am J Orthod Dentofacial Orthop 2012;142:70-4.

32. Almaroof A, Niazi SA, Rojo L, Mannocci F, Deb S. Evaluation of dental adhesive systems incorporating an antibacterial monomer eugenyl methacrylate (EgMA) for endodontic restorations. Dent Mater 2017;33:e239-54.

33. Catunda RQ, Vieira JR, de Oliveira EB, da Silva EC, Brasil VL,
Perez DC, et al. Citotoxicity evaluation of three dental adhesives on vero cells in vitro. J Clin Exp Dent 2017;9:e61-e66.

34. Rizzo M, Evangelista M, Mariani L, Simili M, Rainaldi G, Pitto L, et al. Immortalized mouse embryo fibroblasts are resistant to miR-290-induced senescence regardless of p53 status. Physiol Genomics 2011;43:1153-9.

35. Dioguardi M, Perrone D, Troiano G, Laino L, Ardito F, Lauritano F, et al. Cytotoxicity evaluation of five different dual-cured resin cements used for fiber posts cementation. Int J Clin Exp Med 2015;8:9327-33.

36. Bausch JR, de Lange C, Davidson CL. The influence of temperature on some physical properties of dental composites. J Oral Rehabil 1981;8:309-17.

37. Lovell LG, Lu H, Elliott JE, Stansbury JW, Bowman CN. The effect of cure rate on the mechanical properties of dental resins. Dent Mater 2001;17:504-11.

38. Reis A, Klein-Júnior CA, de Souza FH, Stanislawczuk R, Loguercio AD. The use of warm air stream for solvent evaporation: Effects on the durability of resin-dentin bonds. Oper Dent 2010;35:29-36.

39. Moura SK, Murad CG, Reis A, Klein-Júnior CA, Grande RH, Loguercio AD, et al. The influence of air temperature for solvent evaporation on bonding of self-etch adhesives to dentin. Eur J Dent 2014;8:205-10.

40. Moraes RR, Faria-e-Silva AL, Ogliari FA, Correr-Sobrinho L, Demarco FF, Piva E, et al. Impact of immediate and delayed light activation on self-polymerization of dual-cured dental resin luting agents. Acta Biomater 2009;5:2095-100. 